\title{
Is it possible to measure social entrepreneurship in firms?
}

\section{¿Es posible medir el emprendimiento social en las empresas?}

\author{
Marta Peris-Ortiz ${ }^{1}$ \\ Carlos Rueda-Armengot ${ }^{1}$ \\ Daniel Palacios-Marqués ${ }^{1}$ \\ Universitat Politècnica de València (España)
}

Recibido el 21 de abril de 2014, aceptado el 4 de septiembre de 2015

$\mathrm{N}^{\mathrm{o}}$ de clasificación JEL: L26, L2

DOI: $10.5295 / \mathrm{cdg} .140469 \mathrm{mp}$

\begin{abstract}
:
This study defines and proposes a measurement scale for social entrepreneurship (SE) in its broadest sense. The broad definition of SE covers for-profit firms that use social aims as a core component of their strategy. By pursuing social aims, these firms can boost the value of their products or services for consumers or exploit new business areas. Under this broad definition of SE, profit-seeking and the pursuit of social aims converge, thereby revealing a form of SE that has received little attention in either theoretical or empirical research. To fill this research gap, the present study proposes a measurement scale to measure broad SE in firms. The process used to build the scale draws upon research by Churchill (1979) and DeVellis (1991) and combines the Delphi technique, a pre-test questionnaire and structural equation modelling. The main aim of this research is to develop a scale capable of measuring broad SE in firms. The theoretical basis for the scale is supported by an empirical study in the hotel sector. The scale provides a valid, reliable instrument for measuring broad SE in firms. The scale meets all sociometric properties required of measurement scales in the social sciences, namely dimensionality, reliability and validity.
\end{abstract}

\section{Keywords:}

Social entrepreneurship, social entrepreneurship measurement scale, structural equation modelling.

\section{Resumen:}

Este trabajo define el emprendimiento social (SE) en su dimensión más amplia y propone una escala de medición para el mismo. En lo que se refiere a la dimensión más amplia del SE, esta forma de emprendimiento se refiere a empresas for-profit que incluyen objetivos de carácter social como una parte central de su estrategia, ya que estos objetivos incrementan el valor de sus productos o servicios para los consumidores, o abren nuevas áreas de negocio. De este modo se produce una convergencia entre la búsqueda del beneficio y el cumplimiento de objetivos sociales, poniendo de manifiesto un forma de SE que no ha sido suficientemente definida en la teoría ni investigada en el nivel empírico. De ahí la propuesta de una escala de medición, que constituye el núcleo

\footnotetext{
${ }^{1}$ Dept. Organización de Empresas, Camino de Vera s/n, 46022 Valencia (Spain). mperis@doe.upv.es; crueda@doe. upv.es; dapamar@doe.upv.es
} 
Is it possible to measure social entrepreneurship in firms?

central de este artículo. En la construcción de la escala, se ha seguido un proceso basado en Churchill (1979) y DeVellis (1991), complementado con la técnica Delphi, un cuestionario pre-test y los modelos de ecuaciones estructurales. El objetivo principal es el desarrollo de una escala que mide el emprendimiento social en la empresa. Dicha metodología se apoya en un estudio empírico realizado en el sector de la hostelería. A través del estudio se obtuvo un instrumento válido y fiable para medir el emprendimiento social en las empresas, que satisface todas las propiedades sociométricas exigibles en las escalas de medición en las ciencias sociales: dimensionalidad, fiabilidad y validez.

\section{Palabras clave:}

Emprendimiento social, escala de medición del emprendimiento social, ecuaciones estructurales. 


\section{INTRODUCTION}

Numerous management scholars have defined the concept and content of social entrepreneurship (SE). Nevertheless, the management literature fails to provide a much-needed measurement scale capable of assessing when and to what degree SE is being implemented.

The common thread linking older and more recent SE literature is the role of entrepreneurs in discovering and exploiting new opportunities. Entrepreneurial activity involves 'the study of opportunity sources; the processes of discovery, evaluation, and exploitation of opportunities; and the set of individuals who discover, evaluate, and exploit them' (Shane and Venkataraman 2000, p. 218). Although scholars generally agree on this definition (Venkataraman 1997; Hitt et al. 2001; Barret and Mayson 2008; Peris-Ortiz 2009; Shane 2012), the question of what constitutes entrepreneurship has created a classic division in the literature. Some literature portrays entrepreneurs as discoverers of opportunities within their institutional and economic frameworks (Schumpeter 1934, 1950; Hitt et al. 2001; Veciana et al. 2005), whereas other literature depicts entrepreneurs not as mere discoverers, but rather as agents who exploit such opportunities (Schumpeter 1934, 1950; Lee et al. 2011; Lounsbury and Glynn 2001; Hayton 2005). In addition to these attributes, SE encompasses 'the recognition, evaluation and exploitation of opportunities that result in social value - the basic and long-standing needs of society - as opposed to personal or shareholder wealth' (Certo and Miller 2008, p. 267) and the exploitation of opportunities that result in social value through 'ventures based on profit orientation (...) with the assumption that for-profit and non-profit operations are not mutually exclusive' (Murphy and Coombes 2008, p. 326).

SE therefore has characteristics applicable to both individual and corporate entrepreneurs, yet SE can add value to society through activities in the voluntary and non-profit sector as well as in private business. Focusing on the private sector, Hemingway (2005) and Murphy and Coombes (2008) report that SE can be interpreted as an in-depth extension of a firm's social responsibility: 'an underlying range of basic values that are desirable and important in a civilized society' such as 'freedom, equality, and tolerance, which are germane to the quality of human life' (Ibid.: 326).

As discussed in section 2, SE and corporate social responsibility (CSR) differ. Whereas CSR refers to preventing the firm's products and services from harming the environment or the firm's customers and stakeholders (Carroll 1999), SE refers to placing social considerations at the heart of the firm's strategy. Questions 3 and 6 of the questionnaire (Appendix) exemplify this distinction.

This research conceptualises social entrepreneurship in its broad sense and builds on this conceptualisation to design a social entrepreneurship measurement scale for the evaluation of SE in for-profit firms. The article has the following structure: section 2 conceptualises social entrepreneurship, section 3 describes the method used to build the scale (i.e., Delphi study, pre-test questionnaire and data collection), section 4 presents the verification of the scale's sociometric properties (i.e., dimensionality, reliability and validity), and section 5 offers general conclusions and social implications of the research. 


\section{CONCEPTUALISING SOCIAL ENTREPRENEURSHIP}

As noted above, SE refers to taking individual and corporate aspects of entrepreneurial activity and applying these forms of entrepreneurship to social needs and social problems. In the strict sense, social entrepreneurs seek to create value only (or predominantly) for society (Certo and Miller 2008), whereas, in the broad sense, they combine for-profit activities with the creation of social value (Murphy and Coombes 2008).

In the strict sense (i.e., as a self-contained concept in the entrepreneurship literature), SE is linked to non-profit, voluntary and governmental organisations that pursue social betterment (Austin and Wei-Skillern 2006; Nicholls 2006; Peredo and McLean 2006; Nga and Shamuganathan 2010; Urbano et al. 2010; Morris et al. 2011). Recently, however, authors have emphasised 'the emergence of hybrid entities or new forms of social enterprises that use both elements of the non-profit sector and the for-profit sector' (Urbano et al. 2010, pp. 54-55). Regarding such hybrid entities, an entrepreneurial activity where social improvement is the sole aim cannot take place unless the activity is sustainable - in other words, the activity must make enough profit to support itself financially (Tracey et al. 2011).

Unlike the definition of strict SE, the broad definition of SE extends to profit-driven firms that would include social considerations in their strategy if doing so constituted the best way of increasing value for customers (Waddock and Graves 1997; Sagawa and Segal 2000). This defines SE in its broadest sense and justifies the choice of sector for the empirical study.

Some features of SE in its broad sense are inherent in all forms of SE and overlap with strict SE. Nga and Shamuganathan (2010,pp. 261-263) report that the 'individual personality of social entrepreneurs provides with the impetus to strong will-power that drives their passions (and) innovation (...) to integrate social, environmental and economic aspects'. If this motivation to improve living conditions and distribute socially necessary goods is fulfilled, SE can help to solve problems in social sectors - or societies - that lack government action or incentives for private initiatives (Austin and Wei-Skillern 2006; RidleyDuff 2008). In this vein, SE can be considered an important source of economic, social, cultural and environmental wealth (Spear 2006; Steyeart and Hjorth 2006). Finally, the strict sense of SE transcends what are normally considered philanthropic or charitable actions. SE promotes a more enduring and committed solution to social problems and seeks to create value in innovative and integrative ways (Kurucz et al. 2008).

As previously noted, SE in the broad sense combines profit-seeking and social objectives (Peredo and McLean 2006; Neck et al. 2009), including business ventures that also have social aims. Consequently, a wide range of organisations mix non-profit and for-profit strategies (Fowler 2000; Diochon and Anderson 2011). Likewise, firms that primarily pursue profit may discover that customer service, attention to product quality and care for the environment are positively related to profit. Waddock and Graves (1997) and Sagawa and Segal (2000) have shown that businesses oriented towards financial performance may also have social aims, cooperation initiatives, actions linked to conserving the environment and customer satisfaction programmes, all of which are social components.

This last issue, when coupled with the broader consideration of SE, creates difficulties in defining SE (Audretsch 2012) because companies that combine profit-seeking with social purposes may practise CSR (Carroll 1999; Surroca et al. 2010). But, as previously 
discussed, CSR does not necessarily equate to SE activities. It is difficult to differentiate between CSR and SE, and the literature broadly fails to address how to do so. To retain the broad concept of SE for the proposed measurement scale, however, SE activities can be satisfactorily defined thus: SE constitutes all activities where social objectives form a fundamental part of their strategy. Furthermore, SE activities allow firms to increase value for customers and, accordingly, boost profits while avoiding conflicts between social and financial goals. As previously mentioned, this definition constitutes the broad definition of SE.

Besides highlighting the differences among SE, individual entrepreneurship and corporate entrepreneurship, the definition of SE captures the links and common elements among these forms of entrepreneurship. The intuition and intelligence that lead to the discovery of new ways of integrating social, environmental and economic issues - and of thus creating value for society (SE) - overlap with the personality traits explored in studies of individual entrepreneurship. Furthermore, the way an entrepreneur leads an organisation to achieve cooperation, find new combinations of factors and exploit opportunities are corporate entrepreneurship traits that are also relevant for SE.

A rigorous literature review yielded the items included in the survey. Given this study's novel aim of establishing a broad definition of SE, items were chosen to meet this aim without adhering literally to the items or definitions previously reviewed (Waddock and Graves 1997; Fowler 2000; Sagawa and Segal 2000; Neck et al. 2009; Diochon and Anderson 2011). To measure broad SE, the scale uses the entrepreneurial and social dimensions cited by Peredo and McLean (2006) as components of SE. Another key source was research by Covin and Wales (2012), who argue that, wherever possible, measurement scales should consist of content that is specific to the needs of the research at hand. Next, the expertise of a group of international experts was used to filter the items using the Delphi method. The items were then refined using a pre-test.

To avoid confusion between CSR and SE, the questionnaire scale comprised items that combined the entrepreneurial activity of the firm with its service to people (customers) and other social aspects (society as a whole or the environment). The questionnaire thus addressed the firm's entrepreneurial orientation as a significant strategic issue, while dealing with social aspects related to customers and the environment. The two issues (i.e., entrepreneurial orientation in strategy and social aspects) are inseparable in the questionnaire. The type of entrepreneurial orientation addressed in this study relates to innovations or investments that favour customers, society and the environment.

\section{DEVELOPING A SOCIAL ENTREPRENEURSHIP MEASUREMENT SCALE}

Measurement scales must be tested to ensure they use the most accurate, reliable procedure to gather the relevant information for measurement. The generic procedure used in this study to develop the measurement scale was based on the procedure set forth by Churchill (1979) and DeVellis (1991). All sociometric properties (i.e., dimensionality, reliability and validity) required of measurement scales in the social sciences were also checked. 


\subsection{Building the scale: Literature review, Delphi study and pre-test}

To minimise the length of the measurement instrument and thereby enhance its practical application, the Delphi technique and a pre-test questionnaire were used to select only the relevant attributes (Castrogiovanni et al. 2011). The panel of experts consisted of 18 national and international experts from hospitality firms, academic institutions and public institutions: 4 managers of hotels in large cities, 4 managers at thermal baths, 6 hospitality and tourism scholars (4 from Spain, 1 from France and 1 from Portugal), and 4 tourism and hospitality experts from the public sector. Such variety in the panel of experts reduced information bias.

To check content validity, attributes in the measurement scale were identified in three stages. First, the entrepreneurial orientation and SE literature was reviewed to establish the scale items. Scale items 4,5 and 8 relate to entrepreneurial orientation issues (renovation of ideas in the company, bold investment and capacity to anticipate innovations in the industry). Items 2, 3 and 6 underline the close relationship between entrepreneurial orientation and SE. Items 1 and 7 highlight the need for the firm's products and services to benefit people and the environment, taking into account customers' social and cultural values. The entrepreneurial orientation content of items 2,3,4,5,6 and 8 stems from relevant research into this dimension of company strategy - in particular, work by Kreiser et al. (2002) and, more broadly, work by Covin and Slevin (1989), Covin and Wales (2011) and Morris et al. (2011). The social orientation or SE content of items 1,2,3,6 and 7 draws on the general SE literature. As per Thompson (2002), Tan et al. (2005), Peredo and McLean (2006), Murphy and Coombes (2008), and Neck et al. (2009), SE consists of obtaining products and services that consider customers' cultural and social values, benefit the natural environment, and benefit people or customers by aiding their health or leisure.

Second, after consulting experts, six items were eliminated after two rounds (Delphi method) because of a disagreement among experts. This reduced the number of scale items, thereby making the measurement instrument easier to apply while maintaining its capacity to measure broad SE in firms.

Third and finally, the measurement instrument was pre-tested once with 20 managers from the Spanish hospitality sector. Queries, interpretation difficulties and suggested improvements were assessed and incorporated into the questionnaire items, where appropriate. Appendix presents the final eight items in the SE measurement scale after filtering and refinement.

\subsection{Data gathering}

The study sample was drawn randomly from the list of four- and five-star Spanish hotels registered with the Spanish Institute of Tourism (TurEspaña) in 2011. The population consisted of 1,865 four-star hotels and 241 five-star hotels.

Respondents were hotel managers. The survey, which took place between January and March 2011, yielded 129 questionnaire responses. Of these responses, 9 incomplete questionnaires were discarded to leave a final sample of 120 questionnaires. Technical data for the empirical study appears in Table 1 . 
Table 1

Technical data for the empirical study

\begin{tabular}{|l|l|}
\hline Category & Four- and five-star hotels \\
\hline Research area & Spain \\
\hline Type of interview & semi-structured in-depth interview with the CEO \\
\hline Sample size & 120 firms \\
\hline Sample error & $+/-8.69 \%^{2}$ \\
\hline Date of fieldwork & January 2011 to March 2011 \\
\hline
\end{tabular}

Source: Own elaboration.

\section{SOCIOMETRIC PROPERTIES OF THE SOCIAL ENTREPRENEURSHIP MEASUREMENT SCALE}

A measurement scale comprises items, phrases or questions that enable measurement of a particular attribute that would normally not be directly observable. In this case, the attribute that is not directly observable is broad SE in firms.

The literature review suggests that this scale for measuring broad SE in firms is a novel contribution to the literature. As such, careful verification of all sociometric properties was necessary to ensure the scale's rigour and academic validity. A scale that provides useful, reliable and accurate measurements must meet three requirements (Palacios-Marqués and Garrigós-Simón 2004): dimensionality, reliability and validity.

\subsection{Dimensionality}

Exploratory factor analysis using the varimax method was performed to show the nondimensionality of the social entrepreneurship scale. Only one factor had an Eigenvalue of $100 \%$. Consequently, the factor analysis yielded no measurements to group the items. The scale's theoretical nature meant that verifying dimensionality was unnecessary. Table 2 shows descriptive statistics for the scale.

Table 2

Mean and standard deviation for items on the social entrepreneurship scale

\begin{tabular}{|lcc|}
\hline \multicolumn{1}{|c}{ Item } & $\mathrm{m}$ & $\sigma$ \\
\hline $\begin{array}{l}\text { 1. In this company, we believe that we will build customer loyalty if our products } \\
\text { and services benefit people and/or the environment. }\end{array}$ & 6.08 & 1.25 \\
\hline
\end{tabular}

\footnotetext{
${ }^{2}$ For a confidence level of $95 \%, p=q=50 \%$, in the least favourable case.
} 


\begin{tabular}{|lcc|}
\hline $\begin{array}{l}\text { 2. It is company policy to develop new product lines that benefit society and/or the } \\
\text { environment. }\end{array}$ & 5.98 & 0.79 \\
\hline $\begin{array}{l}\text { 3. The company often invests in developing new services that improve customers' } \\
\text { health or leisure time. }\end{array}$ & 6.32 & 0.91 \\
\hline \begin{tabular}{l} 
4. We boldly seek desired investments and accept the corresponding risk. \\
\hline $\begin{array}{l}\text { 5. The company pays attention to industry news to anticipate product or service } \\
\text { innovation. }\end{array}$
\end{tabular} & 5.07 & 1.02 \\
\hline $\begin{array}{l}\text { 6. The company researches new techniques or procedures that permit innovation } \\
\text { and that benefit the customer and/or the environment. }\end{array}$ & 5.83 & 1.07 \\
\hline 7. The company considers customers' social and cultural values. & 5.36 & 1.14 \\
\hline $\begin{array}{l}\text { 8. The renewal of ideas and their application to product and service innovation is a } \\
\text { characteristic of our company. }\end{array}$ & 5.71 & 1.08 \\
\hline
\end{tabular}

Source: Own elaboration.

Respondents indicated the extent of their agreement on a seven-point Likert scale. CEOs marked 7 to show complete agreement with the item (social entrepreneurship), 4 if social entrepreneurship is present in only some of the company's actions and 1 if social entrepreneurship behaviour is never applied.

Absolute fit, incremental fit and parsimonious fit indices were used to measure the model's goodness of fit. Absolute fit was measured with the Satorra-Bentler Chi-square index (significance $\mathrm{p}$ ) and the RMSR (root mean square residual) index, incremental fit was measured with the BB-NNFI (Bentler-Bonett non-normed fit index) and the IFI (incremental fit index), and parsimonious fit was measured with the NC (normed Chi-square) index. Table 4 shows that the indices yielded excellent values for absolute fit, incremental fit and parsimonious fit measurements, even though the model lacked dimensionality.

\subsection{Reliability}

To ensure reliability, theoreticians must determine the quality of the instruments used. This ensures that the structure of the scale is sound and that the measurements are free from any deviations produced by accidental errors (Hayes 1992, p. 50). To this end, two fundamental conditions must be met: internal consistency and stability of the scale.

Internal consistency means that all variables in the group of operating variables measure the same underlying concept. To check this was the case, the Delphi technique and a pre-test questionnaire were used. The latter indicated the ability of the scale to yield constant results over time. The pre-test procedure yielded no significant differences in the response content.

Table 3

Standardised factor loadings and measurement errors

\begin{tabular}{|lcc|}
\hline \multicolumn{1}{|c|}{ Item } & $\lambda$ & Error \\
\hline $\begin{array}{l}\text { 1. In this company, we believe that we will build customer loyalty if our prod- } \\
\text { ucts and services benefit people and/or the environment. }\end{array}$ & $0.911^{*}$ & 0.412 \\
\hline
\end{tabular}




\begin{tabular}{|c|c|c|}
\hline $\begin{array}{l}\text { 2. It is company policy to develop new product lines that benefit society and/or } \\
\text { the environment. }\end{array}$ & 0.877 & 0.481 \\
\hline $\begin{array}{l}\text { 3. The company often invests in developing new services that improve custom- } \\
\text { ers' health or leisure time. }\end{array}$ & 0.867 & 0.498 \\
\hline 4. We boldly seek desired investments and accept the corresponding risk. & 0.954 & 0.301 \\
\hline $\begin{array}{l}\text { 5. The company pays attention to industry news to anticipate product or service } \\
\text { innovation. }\end{array}$ & 0.766 & 0.643 \\
\hline $\begin{array}{l}\text { 6. The company researches new techniques or procedures that permit innova- } \\
\text { tion and that benefit the customer and/or the environment. }\end{array}$ & 0.883 & 0.471 \\
\hline 7. The company considers customers' social and cultural values. & 0.696 & 0.718 \\
\hline $\begin{array}{l}\text { 8. The renewal of ideas and their application to product and service innovation } \\
\text { is a characteristic of our company. }\end{array}$ & 0.835 & 0.551 \\
\hline
\end{tabular}

Source: Own elaboration.

Reliability was measured using Fornell and Larcker's (1981) coefficient with standardised loadings and measurement errors. The minimum reliability rate was set at 0.7 . Table 3 shows the values for the measurement scale's loadings and measurement errors.

Parameters marked * were set to 1 to fix the latent variable scale. All estimated parameters were statistically significant at $95 \%(t>1.96)$. The values of the standardised loadings were high: Most loadings were greater 0.6 , and all loadings were greater than 0.4 , which is the minimum suggested by Hair et al. (1999). Combined reliability (0.89) exceeded the minimum threshold. This result implies that the items chosen to measure broad social entrepreneurship are reliable.

\subsection{Validity}

Validity measures the goodness of fit of the object variable using the mean of the measurement scale. A valid measurement is free of systematic and random errors (Churchill 1979). Content validity and convergent validity were determined.

\section{A. Content validity}

Content validity of scale items can be achieved through theoretical argument and/or by relying on existing empirical studies and scales in the literature. As shown in section 3.1, the literature assures the content validity of the items in the proposed scale. Furthermore, content validity for the scale was achieved because the scale was created in accordance with procedures taken from the literature (Churchill 1979).

\section{B. Convergent validity}

A construct has convergent validity when the measurement being assessed correlates strongly with other measurements that assess the same construct (Churchill 1979, p. 70). To confirm this condition, the following measures were used: the Bentler-Bonett coefficient (Bentler and Bonett 1980), which must be greater than 0.9, the factor loadings (Bollen 1989), which must be greater than 0.4, and the t-values (Anderson and Gerbing 1982), which must be statistically significant. Table 4 shows the fit indices for the measurement model. 
Table 4

Fit indices for the measurement model

\begin{tabular}{|c|c|c|c|c|c|c|}
\hline d.f. & Chi $^{2}$ & P & BB NNFI & IFI & RMSR & NC \\
\hline 20 & 27.19 & 0.130 & 0.978 & 0.978 & 0.031 & 1.62 \\
\hline
\end{tabular}

Source: Own elaboration.

The goodness of fit according to the BB-NNFI indicator (0.978) and the size of the factor loadings (see Table 3) confirm convergent validity of the measurement scale. All factor loadings were greater than 0.4, as recommended by Hair et al. (1999). Furthermore, the estimated parameters were statistically significant at $95 \%$ ( $\mathrm{t}>1.96$ ). Table 4 shows that the absolute fit, incremental fit and parsimonious fit measurements demonstrate excellent fit. Therefore, this scale also satisfied all sociometric properties demanded of measurement scales in the social sciences.

\section{CONCLUSIONS}

Section 2 on the conceptualisation of social entrepreneurship explains how SE encompasses fundamental aspects of individual and corporate entrepreneurship. The same section shows the distinction between strict and broad SE. In the strict sense, SE is linked to non-profit, voluntary and governmental organisations that aim to resolve social problems or needs. This classical form of SE gives SE its status as a specific, self-contained form of entrepreneurship. In a broad sense, however, SE also applies to for-profit companies with social objectives. Such firms' main concern is making profit, but these firms' strategies use customer service and/or care for the environment to boost profits.

This broad definition of SE is particularly important in this study and in the proposed measurement scale because the scale is validated for for-profit companies for which profit-seeking was a main objective. Although SE in the broad sense is difficult to distinguish from CSR, the questionnaire manages to differentiate between SE and CSR by focusing on aspects of general and social entrepreneurship. The four- and five-star hotels in the sample used to validate the proposed scale offer services to improve customers' health (e.g., spas and natural surroundings) or provide cultural services by dedicating some of their resources to exhibitions or other social activities. These hotels thereby combine entrepreneurship, social activities and profit-seeking.

The scale items were designed in relation to representative studies in entrepreneurial orientation and SE literature. For some items (2,3,4, 5, 6 and 8), entrepreneurial orientation is a characteristic of the companies studied, whereas items 1,2,3,6 and 7 stem from the SE literature in general. The questionnaire items reflect the idea that firms can address customer service and the environment while still making a profit. These items on the measurement scale, obtained through an extensive literature review, yield a valid, reliable scale to measure firms' SE in the broadest sense of the term. Thus, the main contributions of this article are characterising broad SE in terms of the scale items and verifying the scale by examining its sociometric properties.

The most obvious limitations of the proposed scale stem from its validation in a single sector. Nevertheless, many other production or service sectors (e.g., car manufacturing and health 
or therapeutic services) could be analysed using the proposed scale. These sectors resemble the hospitality sector because benefits for customers' health or the environment directly translate into competitiveness and profit-making ability. In future research, it would be of interest to analyse whether firms with social entrepreneurship behaviour perform better financially in other sectors or industries.

A social implication of this research, which needs to be confirmed by further study, is that, in at least some sectors of an advanced society, profit-seeking tends to converge with policies and strategies oriented towards benefitting consumers or society in general.

\section{ACKNOWLEDGEMENTS}

The authors gratefully acknowledge financial support from the Universitat Politècnica de València through the project Paid-06-12 (Sp 20120792).

\section{REFERENCES}

Anderson, J. C. and Gerbing, D. W., 1982. Some methods for respecifying measurement models to obtain multidimensional constructs measures. Journal of Marketing Research, 19, 453-460.

Audretsch, D., 2012. Entrepreneurship research. Management Decision, 50, 755-764.

Austin, J. S. H. and Wei-Skillern, J., 2006. Social and commercial entrepreneurs: same, different, or both? Entrepreneurship Theory and Practice, 30, 1-23.

Barret, R. and Mayson, S., 2008. Introduction: at the intersection of entrepreneurship and human resource management. In R. Barret\& S. Mayson (eds.). International handbook of Entrepreneurship and HRM. Cheltenham, UK: Edward Elgar, 1-17.

Bentler, P. M. and Bonett, D. G., 1980. Significance tests and goodness-of-fit in the analysis of covariance structures. Psichological Bulletin, 88, 588-606.

Bollen, K. A., 1989. Structural equations with latents variables. New York: John Wiley and Sons.

Carroll, A. B., 1999. Corporate social responsibility: evolution of a definitional construct. Business \& Society, 38, 268-295.

Castrogiovanni, G. J., Garrigós-Simón, F. and Peris-Ortiz, M., 2011. Human resource management practices and the importance of manager's perceptions. Canadian Journal of Administrative Sciences, 28, 2, 122-133

Certo, S. T. and Miller, T., 2008. Social entrepreneurship: Key issues and concepts. Business Horizons, 51, 267-271.

Churchill, G. A., 1979. A paradigm for developing better measures of marketing constructs. Journal of Marketing Research, 16, 64-73.

Covin, J. G. and Slevin, D. P., 1989. Strategic management of small firms in hostile and benign environments. Strategic Management Journal, 10, 75-87.

Covin, J. G. and Wales, W. J., 2011. The measuremet of entrepreneuria orientation. Entrepreneurship Theory and Practice, July, 677-702.

DeVellis, R. F., 1991. Scale development: theory and applications. Newbury Park, California: Sage Publications. 
Díaz Foncea, M. and Marcuello Serós, C., 2012. Social entrepreneurship and social markets: models and new trends. Service Business, January, 61-83.

Diochon, M. and Anderson, A. R., 2011. Ambivalence and ambiguity in social enterprise; narratives about values in reconciling purpose and practices. International Entrepreneurship and Management Journal, 7, 93-109.

Fornell, C. and Larcker, D. F., 1981. Evaluating structural equations models with unobsevable variables and measurement error. Journal of Marketing Research, 18, 39-50.

Fowler, A., 2000. NGDOs as a moment in history: beyond aid to social entrepreneurship or civic innovation? Third World Quarterly, 21, 637-654.

Hair, H. F., Anderson, R. E., Tahman, R. L. and Black, W. C., 1999. Multivariate analysis. NewYork: Prentice Hall.

Hayes, B., 1992. Measuring customer satisfaction: development and use of questionnaires. Milwaukee: The Quality Press.

Hayton, J. C., 2005. Promoting corporate entrepreneurship through human resource management practices: a review of empirical research. Human Resource Management Review, 15, 21-41.

Hemingway, C. A., 2005. Personal values as a catalyst for corporate social entrepreneurship. Journal of Business Ethics, 60, 233-249.

Hitt, M. A., Ireland, R. D., Camp, S. M. \& Sexton, D. L., 2001. Guest editors' introduction to the special issue strategic entrepreneurship: entrepreneurial strategies for wealth creation. Strategic Management Review, 22, 479-491.

Kreiser, P. M., Marino, L. D. and Weaver, K. M., 2002. Assessing the psychometric properties of the entrepreneurial orientation scale: a multi-country analysis. Entrepreneurship Theory and Practice, 26, 4, 71-94.

Kurucz, E. C., Colbert, B. A. and Wheeler, D. C., 2008. The business case for Corporate Social Responsibility, in A. Crane, A. McWilliams, D. Matten, J. Moon and D. Siegel (eds.). The Oxford Handbook on Corporate Social Responsibility. Oxford: Oxford University Press.

Lee, S. L., Peris-Ortiz, M. and Fernández-Guerrero, R., 2011. Corporate entrepreneurship and human resource management: theoretical background and a case study. International Journal of Manpower, 32, 48-67.

Lounsbury, M. and Glynn, M. A., 2001. Cultural entrepreneurship: Stories, legitimacy and the acquisition of resources. Strategic Management Journal, 22, 545-564.

Morris, M. H., Webb, J. W. and Franklin, R. J., 2011. Understanding the manifestation of entrepreneurial orientation in the non profit context. Entrepreneurship Theory and Practice, September, 947-971.

Murphy, P. J. and Coombes, S. M., 2008. A model of social entrepreneurial discovery. Journal of Business Ethics, 87, 325-336.

Neck, H., Brush, C. and Allen, E., 2009. The landscape of social entrepreneurship. Business Horizons, 52, 13-19.

Nga, J. K. H. and Shamuganathan, G., 2010. The influence of personality traits and demographic factors on social entrepreneurship start up intentions. Journal of Business Ethics, 95, 259-282.

Nicholls, A., 2006. Playing the field: a new approach to the meaning of social entrepreneurship. Social Enterprise Journal, 2, 1-5. 
Palacios-Marqués, D. and Garrigós-Simón, F., 2004. A measurement scale for knowledge management in the biotechnology and telecomunications industries. International Journal Technology Management, 10, 1-17.

Peredo, A. M. and McLean, M., 2006. Social entrepreneurship: A critical review of the concept. Journal of World Business, 41, 56-65.

Peris-Ortiz, M., 2009. An analytical model for human resource management as an enabler of organizational renewal: a framework for corporate entrepreneurship. International Entrepreneurship Management Journal, 5, 461-479.

Ridley-Duff, R., 2008. Social enterprise as a socially rational business. International Journal of Entrepreneurial Behaviour \& Research, 14, 291-312.

Sagawa, S. and Segal, E., 2000. Common interest, common good: creating value through business and social sector partnership. California Management Review, 42, 105-122.

Schumpeter, J. A., 1934. The theory of economic development. Cambridge, MA: Harvard University Press.

Schumpeter, J. A., 1950. Capitalism, socialism and democracy ( $3^{\text {rd }}$ Ed.). New York: Harper \& Row.

Shane, S., 2012. Reflections on the 2010 AMR decade Award: delivering on the promise of entrepreneurship as a field of research. Academy of Management Review, 37, 10-20.

Shane, S. and Venkataraman, S., 2000. The promise of entrepreneurship as a field of research. Academy of Management Review, 25, 217-226.

Spear, R., 2006. Social entrepreneurship: a different model? International Journal of Social Economics, 33,399-410.

Steyaert, C. and Hjorth, D., 2006. Entrepreneurship as social change: A third movements in entrepreneurship book. Cheltenham, UK: Edward Elgar.

Surroca, J., Tribó, J. A. and Waddock, S., 2010. Corporate responsibility and financial performance: the role of intangible resources. Strategic Management Journal, 31, 463-490.

Tan, W-L., Williams, J. and Tan, T-M., 2005. Defining the 'social' in social entrepreneurship: Altruism and entrepreneurship. International Entrepreneurship and Management Journal, 1, 353-365.

Thompson, J. L., 2002. The world of the social entrepreneur. International Journal of Public Sector Management, 15, 412-431.

Tracey, P., Phillips, N. and Jarvis, O., 2011. Bringing institutional entrepreneurship and the creation of new organizational forms: a multilevel model. Organization Science, 22, 6080 .

Urbano, D., Toledano, N. and Ribeiro Soriano, D., 2010. Analyzing social entrepreneurship from an institutional perspective: evidence from Spain. Journal of Social Entrepreneurship, 1, 54-69.

Veciana, J.M., Aponte, M. and Urbano, D., 2005. University students' attitudes towards entrepreneurship: A two countries comparison. International Entrepreneurship and Management Journal, 1, 2, 165-182.

Venkataraman, S., 1997. The distinctive domain of entrepreneurship research: An editor's perspective. In J. Katz \& R. Brockhaus (eds.). Advances in entrepreneurship, firms emergence, and growth (vol. 3, 119-138), Greenwich, CT: JAI Press.

Waddock, S. A. and Graves, S. B., 1997. The corporate social performance-financial performance link, Strategic Management Journal, 18, 303-319. 


\section{APPENDIX}

\section{Social Entrepreneurship Measurement scale}

1. In this company, we believe that we will build customer loyalty if our products and services benefit people and/or the environment.

2. It is company policy to develop new product lines that benefit society and/or the environment.

3. The company often invests to introduce new services that improve customers' health or leisure time.

4. We boldly seek desired investments and accept the corresponding risk.

5. The company pays attention to industry news to anticipate product or service innovation.

6. The company researches new techniques or procedures that permit innovation and that benefit the customer and/or the environment.

7. The company considers customers' social and cultural values.

8. The renewal of ideas and their application to product and service innovation is a characteristic of our company. 